\title{
EVALUATION OF COMBUSTION PROPERTIES OF BIOMASS FUEL
}

\author{
Aleksandrs Adamovics, Rasma Platace, Aivars Kakitis, Semjons Ivanovs \\ Latvia University of Life Sciences and Technologies, Latvia \\ aleksandrs.adamovics@llu.lv, rasmins@inbox.lv, aivars.kakitis@1lu.lv, semjons@apollo.lv
}

\begin{abstract}
Carbon and hydrogen are the main burning elements of biomass fuel that affect the calorific value of fuel. Combustion heat of hydrogen significantly exceeds the heat of carbon combustion, so biomass with higher hydrogen content has a relatively higher calorific value. The study found that the carbon content of various grass species (reed canary grass, festulolium, timothy, meadow fescue, and tall fescue) varied from $42.00 \%$ formeadow fescue to $48.97 \%$ fortimothy. Hydrogen content in the samples analysed was, however, between $5.48 \%$ (for timothy) and $5.93 \%$ (for reed canary grass). The hydrogen-to-carbon (H/C) ratio for grasses variedfrom 1.45 for timothy to 1.52 for reed canary grass. The calculation of the H/C ratio for grass biomass as well as the effect of the nitrogen fertilizer dose on the hydrogen and carbon content of biomass are described in the present article. A conclusion is drawn that the calorific value of biomass fuel is significantly affected by the carbon content. In contrast, the increased lignin content against cellulose and hemicellulose increases the calorific value of the fuel at the same carbon content. The increase in hydrogen - carbon ratio reduces the gross calorific value.
\end{abstract}

Keywords: grass species, carbon content, hydrogen content, hydrogen-to-carbon ratio.

\section{Introduction}

The main combustible chemical elements of biomass fuels are carbon (C) and hydrogen (H). Sulphur (S) is also a combustible material, but its impact on the calorific value of fuel is low. In combustion sulphur produces harmful emissions in the form of sulphur oxides that pollute the environment and cause corrosion of the equipment. The oxygen $(\mathrm{O})$ contained in fuel contributes to combustion, but generally reduces the calorific value of fuel. Also, nitrogen $(\mathrm{N})$ content has a negative effect on the calorific value of fuel [1]. During combustion $\mathrm{C}$ and $\mathrm{H}$ are oxidized, and exothermic reactions lead to the formation of $\mathrm{CO}_{2}$ and $\mathrm{H}_{2} \mathrm{O}$ [2].

The calorific value of a fuel depends on its $\mathrm{C}, \mathrm{H}, \mathrm{O}$, and $\mathrm{N}$ content. Increase in the $\mathrm{H}$ and $\mathrm{C}$ content in biomass increases its higher heating value (HHV), but the increase in the $\mathrm{O}$ content in biomass decreases its calorific value [3;4]. Carbon is the main burning element of fuel that can be used to generate energy in the form of heat, which can then be converted into other forms of energy mainly in thermal energy. The calorific value of pure carbon is $34 \mathrm{MJ} \cdot \mathrm{kg}^{-1}$. Hydrogen is the second main burning element; its calorific value is considerably higher $\left(Q_{a}=141.8 \mathrm{MJ} \cdot \mathrm{kg}^{-1}\right)$ than that of carbon. Hydrogen content in biomass ranges between 3 and $11 \%$ (6.3\% on average), which is more than the average for fossil fuels (5.4\%) [5]. The above-mentioned elements have a significant effect on the calorific value of fuel, i.e. the increase in the $\mathrm{C}$ and $\mathrm{H}$ content significantly increases the higher calorific value of fuel $[3 ; 4]$.

The fuel classification based on the element $(\mathrm{H} / \mathrm{C})$ ratio allows a better understanding of the factors influencing its calorific value. As a result of the research, it has been found that with increasing the $\mathrm{H} / \mathrm{C}$ ratio, the calorific value of fuel decreased [6]. Also, the oxygen/carbon $(\mathrm{O} / \mathrm{C})$ ratio has a significant impact on the calorific value of fuel. It has been found that, when the $\mathrm{O} / \mathrm{C}$ ratio changed from 0.1 to 0.7 , the calorific value increased on average from 15 to $38 \mathrm{MJ} \cdot \mathrm{kg}^{-1}$ [6]. In biomass fuels (wood, grasses, straw, etc.) carbon and hydrogen are components of cellulose, hemicellulose, and lignin. The proportions of these components in fuel depend on many factors. From the viewpoint of the calorific value of fuel, it is important to ensure a proportion between the components, which allows obtaining the highest calorific value with minimum investments. The increase in the ratio of lignin/cellulose + hemicellulose increases also the calorific value of fuel [1].

The aim of the study was to find out the effect of afertilizer dose on the H/C ratio and the change in the proportion of lignin/cellulose + hemicellulose, and their effect on the gross calorific value of the grass biomass.

\section{Materials and methods}

Experiments were carried out with six types of cereal grasses: reed canary grass (Phalarisarundinaceae (L.) Raush.), cultivar 'Marathon'; festulolium ( $\times$ Festulolium Asch. 
\&Graebn.), cultivar 'Vetra'; timothy (Phleumpratense L.), cultivar 'Teicis'; meadow fescue (Festucapratensis Huds.), cultivar 'Vaira'; tall fescue (Festucaarundinaceae Schreb.), cultivar 'Fawn'. The following fertilizer variants were used for all types of cereal grasses: NOPOK0 - control, and P80K120 - background fertilizer (F).Six pre-plant fertilizer variants with the following nitrogen fertilizer rates were used: $\mathrm{F}+30, \mathrm{~F}+60, \mathrm{~F}+90, \mathrm{~F}+120, \mathrm{~F}+150$, and $\mathrm{F}+180 \mathrm{~kg} \mathrm{ha}^{-1} \mathrm{~N}$. The experimentsincluded 48 variants. The area of the experimental fields was $10 \mathrm{~m}^{2}$, with a $2-\mathrm{m}$ wide aisle between cereal grass species. The option layout was randomized [7].

Harvesting was carried out by cutting the grass $5-6 \mathrm{~cm}$ high with the grass harvester "HansUlrichHege 212".The weight of the green mass was calculated electronically, determining the yield of each replicate in the field.

The following methods were used for determination of the chemical composition of biomass (\%): carbon content - by the analyser"CS-500"; hydrogen content - according to ISO 625 LVS EN 15104; lignin content - according to LVS EN ISO 13906:2008; cellulose = ADF - lignin; and hemicellulose $=\mathrm{NDF}-\mathrm{ADF}$. Measurement errors: $\pm 0.1 \%$ for carbon, $\pm 0.2 \%$ for hydrogen.

Chemical analyses were carried out at the Scientific Laboratory of Agronomic Analysis of the Latvia University of Life Sciences and Technologies and at the Waste and Fuel Research and Testing Laboratory "Virsma" in Riga. Measurement uncertainty was $\pm 3 \%$. The data were mathematically processed using"Microsoft Excel" and SPSS program packages.The errors of the results of experiments were calculated using statistical methods and parameters at the confidence level $95 \%$. Calculations were proceeded using methods of correlation and factor analysis.

\section{Results and discussion}

Carbon content inthe investigated grasses varied from $42.00 \%$ (for meadow fescue in 2013) to $48.97 \%$ (for timothy in 2012) (Table 2).These indices were less than those reported in other studies, where the $\mathrm{C}$ content in grasses fluctuated between 49 and $50 \%$ [8;9]. The most widely used grass for the production of thermal energy is reed canary grass. The results of our investigations showed that the Ccontent in this grass varied from $42.04 \%$ in 2013 to $47.88 \%$ in 2018(in the first mowing from late June to early July yielding). In a research conducted in Latvia by the Agricultural Science Centre of Latgale (2009-2010), the Ccontent of barley cultivars 'Marathon' and 'Bamse' was found to be from $37.45 \%$ to $41.88 \%$ in October [10].In a research conducted by the Latvian State Forest Research Institute "Silava", the $C$ content in the dry matter of barley was on average $49 \%$ [11]. Similarly, the biologists Bridgeman, Jones, Shield, and Williams established that barley dry matter contained on average $48.6 \%$ of carbon [12].

In other grass species included in our study the carbon content varied from $42.31 \%$ to $47.91 \%$ intall fescue, from $42.11 \%$ to $48.97 \%$ in timothy, from $42.00 \%$ to $48.27 \%$ in meadow fescue, and from $42.33 \%$ to $46.40 \%$ in reed canary grass (Table 1). Comparing the results obtained in two years, it can be concluded that the $\mathrm{C}$ content varied, which can be explained by the different meteorological conditions in the respective years. In 2012 the average $C$ content in all grass species was $47.49 \%$, but in 2013 it was $10.5 \%$ lower, i.e. $42.51 \%$.

Without fertilizer use the average C content was $44.93 \%$ (varied from $42.90 \%$ to $47.43 \%$ ). The phosphorus and potassium (P80K120) background fertilizer did not contribute to the increase in the $\mathrm{C}$ content; however, with $\mathrm{N}$ fertilizer, the $\mathrm{C}$ content, using all $\mathrm{N}$ fertilizer doses, increased slightly on average by $1 \%$, when using a nitrogen norm of $30 \mathrm{~kg} \cdot \mathrm{ha}^{-1} \mathrm{~N}$, and by $2 \%$, when using anitrogen norm of $180 \mathrm{~kg} \cdot \mathrm{ha}^{-1} \mathrm{~N}$.The research demonstrated that the increase in the $\mathrm{N}$ fertilizer rate compared to the background fertilizer (P80K120) did not significantly change the amount of carbon in biomass (Fig. 1). For some grasses, as the $\mathrm{N}$ fertilizer rate increased, the $\mathrm{C}$ content remained constant or only slightly decreased. The increase in the $\mathrm{C}$ content was observed only for reed canary grass.

From Fig. 2 it can be concluded that for the majority of grass species the dose of $\mathrm{N}$ fertilizer did not have a significant effect on the ratio of lignin to the total amount of cellulose and hemicellulose (L/Cel). Only for reed canary grass the increase in the dose of fertilizer to180 $\mathrm{kg} \cdot \mathrm{ha}^{-1}$ decreased the $\mathrm{L} / \mathrm{Cel}$ ratio by $21 \%$. For all grasses, with the increase in the $\mathrm{N}$ fertilizer dose, the lignin-to-cellulose ratio decreased only slightly. Thus, a conclusion can be drawn that increasing in the $\mathrm{N}$ dose over $60 \mathrm{~kg} \cdot \mathrm{ha}^{-1}$ is not recommended. The highest L/Cel ratio was observed for timothy. This correlates with 
the hypothesis of the positive effect of lignin on the higher calorific value, which is illustrated in Fig. 3, showing that the highest calorific value was found just for timothy.

Table 1

Carbon and hydrogen content in the dry matter of grass species biomass depending on the fertilizer rate

\begin{tabular}{|c|c|c|c|c|c|c|c|c|c|c|}
\hline \multirow[t]{2}{*}{ Fertilizer } & \multicolumn{2}{|c|}{$\begin{array}{l}\text { Reed canary } \\
\text { grass }\end{array}$} & \multicolumn{2}{|c|}{ Festulolium } & \multicolumn{2}{|c|}{ Timothy } & \multicolumn{2}{|c|}{ Meadow fescue } & \multicolumn{2}{|c|}{ Tall fescue } \\
\hline & 2012 & 2013 & 2012 & 2013 & 2012 & 2013 & 2012 & 2013 & 2012 & 2013 \\
\hline \multicolumn{11}{|c|}{ Carbon (C) content, $\%$} \\
\hline NOPOK0 & 47.43 & 42.90 & 46.48 & 42.62 & 48.81 & 42.44 & 47.89 & 42.13 & 46.40 & 42.58 \\
\hline P80K120 (F) & 47.12 & 42.04 & 46.85 & 43.09 & 48.05 & 42.63 & 48.19 & 42.52 & 46.21 & 42.93 \\
\hline $\mathrm{F}+\mathrm{N} 30$ & 47.28 & 42.84 & 47.02 & 42.52 & 48.74 & 43.00 & 48.02 & 42.19 & 46.12 & 42.83 \\
\hline $\mathrm{F}+\mathrm{N} 60$ & 47.51 & 42.43 & 47.14 & 42.31 & 48.06 & 42.71 & 48.08 & 42.27 & 45.99 & 42.31 \\
\hline $\mathrm{F}+\mathrm{N} 90$ & 47.73 & 42.95 & 47.62 & 42.36 & 48.51 & 42.24 & 47.15 & 42.00 & 46.07 & 42.69 \\
\hline $\mathrm{F}+\mathrm{N} 120$ & 47.50 & 42.88 & 47.91 & 42.36 & 48.97 & 42.11 & 48.27 & 42.12 & 46.00 & 42.66 \\
\hline$F+N 150$ & 47.88 & 42.61 & 47.13 & 42.58 & 48.89 & 42.23 & 48.12 & 42.21 & 46.24 & 42.54 \\
\hline $\mathrm{F}+\mathrm{N} 180$ & 47.84 & 42.76 & 47.90 & 42.82 & 48.41 & 42.15 & 48.27 & 42.14 & 46.91 & 42.76 \\
\hline $\mathrm{Sd}^{1)}$ & 0.27 & 0.31 & 0.51 & 0.27 & 0.36 & 0.32 & 0.37 & 0.15 & 0.30 & 0.19 \\
\hline $\mathrm{Sx}^{2)}$ & 0.09 & 0.11 & 0.18 & 0.09 & 0.13 & 0.11 & 0.13 & 0.05 & 0.11 & 0.07 \\
\hline \multirow{2}{*}{\multicolumn{11}{|c|}{ Hydrogen $(\mathrm{H})$ content, $\%$}} \\
\hline rage & & & & & & & & & & \\
\hline
\end{tabular}

${ }^{1)} \mathrm{Sd}$ - mean arithmetic representation error; ${ }^{2)} \mathrm{Sx}$ - difference representation error

The content of hydrogen in the samples of the grasses analysed varied from $5.48 \%$ for timothy to $5.93 \%$ for tall fescue (Table 1).



Fig. 1. Carbon content depending on fertilizer rate

In this study the carbon-to-hydrogen ratio was the highest for tall fescue (1.52) and the lowest for timothy grass (1.45) (Fig. 3).Analyzing the changes in the lignin, cellulose and hemicellulose content depending on the $\mathrm{N}$ fertilizer rate, it was concluded that the increase in the $\mathrm{N}$ fertilizer rate increased the proportion of cellulose and hemicellulose in biomass. The exception was festulolium, which has a high $\mathrm{C} / \mathrm{H}$ ratio (1.51), while the ratio of lignin to cellulose and hemicellulose is low (only 0.097). When evaluating the highest calorific value of festulolium, we can see that it reaches $16.45 \mathrm{MJ} \cdot \mathrm{kg}^{-1}$, which is one of the highest among the investigated grasses. This means that extended research is needed to find the causes that led to such aresult. 


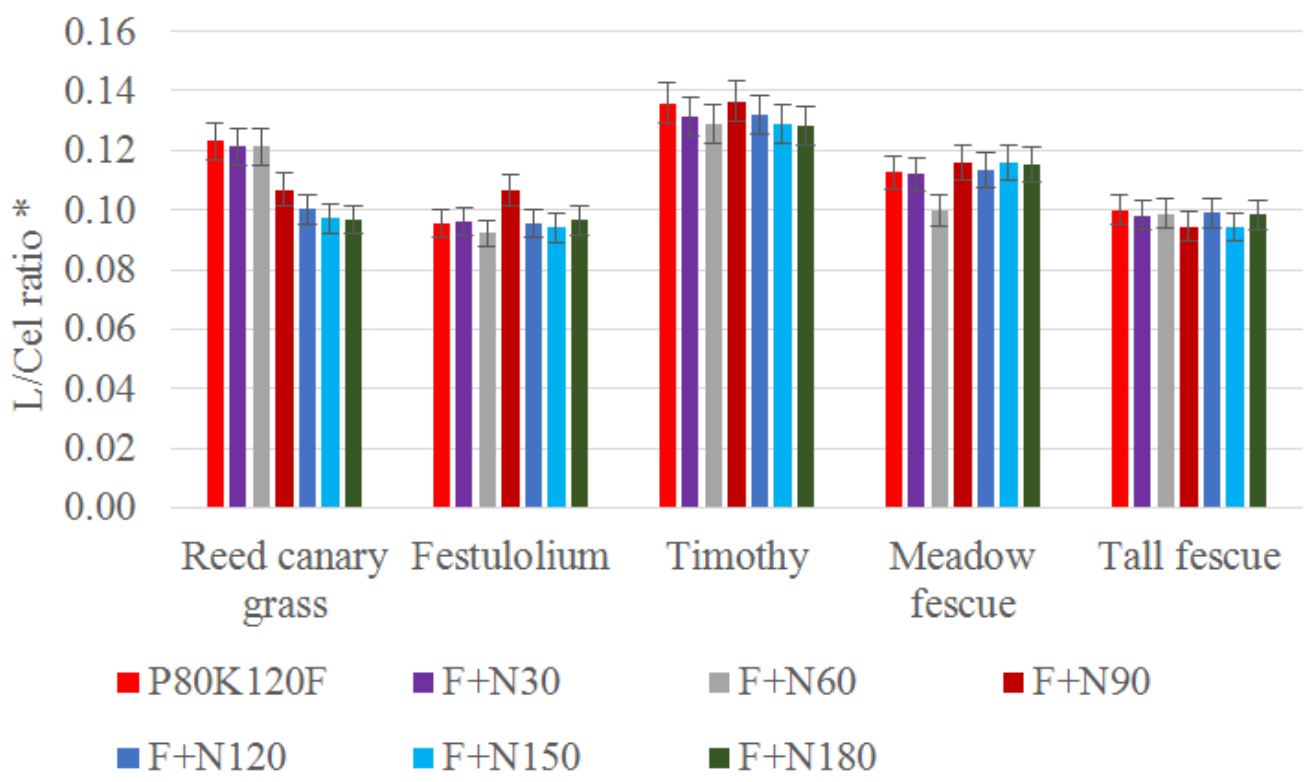

Fig. 2. L/Cel ratio depending on nitrogen fertilizer dose

(*L/Cel- ratio of lignin content to the total quantity of cellulose and hemicellulose)



Fig. 3. H/C, L/Cel, and higher calorific value $\boldsymbol{Q}_{a}$ of various biomasses $(0.1 \times \mathrm{H} / \mathrm{C}$ - hydrogen-tocarbon ratio divided by $10, \mathrm{~L} / \mathrm{Cel}$ - ratio of lignin content to the total quantity of cellulose and hemicellulose)

The lignin content did not change significantly, leading to a decrease in the proportion of lignin. Fig. 3 shows the mean values for the ratio of lignin to cellulose + hemicellulose for all investigated grasses. The highest $\mathrm{L} / \mathrm{Cel}$ ratio was found for timothy (0.13), but the lowest - for tall fescue and festulolium (0.097-0.098). The difference is significant and reaches $25 \%$. In the same chart we can see that the $\mathrm{H} / \mathrm{C}$ ratio does not differ significantly for all investigated grasses.

It was found that the ratio of lignin to cellulose affected the gross calorific value of biomass. Fig. 4a demonstrates thatthe increase in the lignin-to-cellulose + hemicellulose ratio increases also the gross calorific value.

A conclusion was drawn that with an increase in the $\mathrm{L} / \mathrm{Cel}$ ratio of $25 \%$, the calorific value increased by an average of $6 \%$. When evaluating the effect of the $\mathrm{H} / \mathrm{C}$ ratio on the calorific value of biomass fuel, itcan be concluded that with the increase in the $\mathrm{H} / \mathrm{C}$ ratio the gross calorific value of the fuel decreases (Fig. 4b). For the grasses assessed in the experiments the reduction in the calorific value 
reached $9 \%$ at the $\mathrm{H} / \mathrm{C}$ ratio changing from 1.45 to 1.52 . The results obtained coincide with the results of other researchers' experiments.

a)

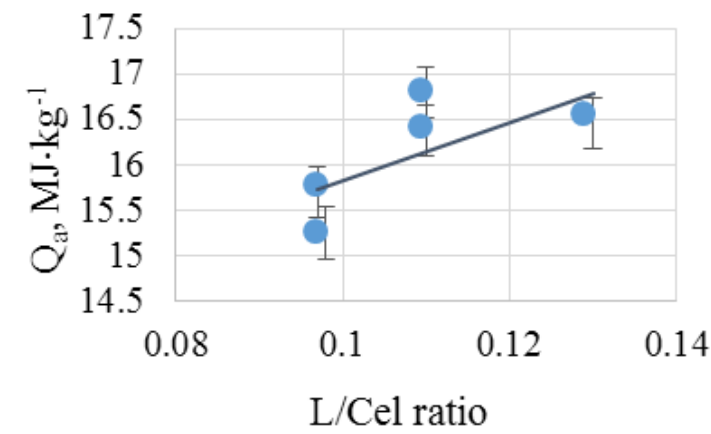

b)



Fig. 4. Gross calorific value $\left(Q_{a}\right)$ depending on ratio of burning elements: $\mathrm{a}-Q_{a}$ depending on $\mathrm{L} / \mathrm{Cel}$ ratio; $\mathrm{b}-Q_{a}$ depending on $\mathrm{H} / \mathrm{C}$ ratio

\section{Conclusions}

1. Carbon content has a significant impact on the calorific value of biomass fuel, but its content does not change significantly depending on the nitrogen fertilizer rate. Change in the nitrogen fertilizer rate compared to the background fertilizer from 30 to $180 \mathrm{~kg} \cdot \mathrm{ha}^{-1}$ increased the average carbon content by only $2 \%$.

2. Increase in the hydrogen-to-carbon ratio reduces the calorific value of biomass fuel. For the grasses assessed in the experiments the reduction in the calorific value reached $9 \%$ at the $\mathrm{H} / \mathrm{C}$ ratio changing from 1.45 to 1.52 .

3. Increase in the ratio of lignin to cellulose + hemicellulose of $25 \%$ increased the gross calorific value by an average of $6 \%$.

4. The ratio of lignin to cellulose + hemicellulose does not increase significantly by increasing the nitrogen fertilizer rate for most of the investigated grass biomasses. The exception is reed canary grass: increase in the nitrogen fertilizer rate from $60 \mathrm{~kg} \cdot \mathrm{ha}^{-1}$ to $180 \mathrm{~kg} \cdot \mathrm{ha}^{-1}$ decreased the ratio of the lignin content to cellulose + hemicellulose from 0.122 to 0.097 .

\section{References}

[1] Acar S., Ayanoglu S. Determination of higher heating values (HHVs) of biomass fuels. Energy Education Science and Technology Part A: Energy Science and Research, Volume (issues) 28(2), 2012, p. 749-758

[2] Obernberger I., Brunner T., Barnthaler G. Chemical properties of solid biofuels - significance and impact. Biomass and Bioenergy, No. 30, 2006. pp. 973-982.

[3] Spliethoff H. Power Generation from Solid Fuels. Springer,2010, 674 p.

[4] Saidur R., Abdelaziz E.A., Demirbas A. etc. A review on biomass as a fuel for boilers. Renewable and Sustainable Energy Reviews, No. 15, 2011. pp. 2262-2289.

[5] Vassilev S.V., Baxter D., Andersen L.K., Vassileva C.G. An overview of the composition and application of biomass ash. Part 2: Potential utilisation, technological and ecological advantages and challenges. Fuel, No. 105, 2013, pp. 19-39.

[6] Jones J.M., Nawaz M., Darvell L.I., Ross A.B., Pourkashanian M., Williams A. Towards biomass classification for energy applications. In: Science in Thermal and Chemical Biomass Conversion. A.V. Bridgwater, D.G.B. Boocock (Eds.).Vol. 1. CPL Press, 2006, pp. 331-339.

[7] Adamovics A., Platace R., Gulbe I. Influence of nitrogen fertilizeron grass biomass yield and amount of energy gained per areaunit. Inproceedings of 17th International scientific conference "Engineering for rural development", Jelgava, Latvia, May 23-25, 2018 Vol. 17, pp. 1628.-1631.

[8] Vassilev S.V., Baxter D., Andersen L.K. et al. An overview of the chemical composition of biomass. Fuel, (5), 2010, pp. 913-933

[9] Belicka I., Miglāne V., Jansone Z. Suitability of spring cereals for production of heat energy. Environment. Technology. Resources Proceedings of the 7th International Scientific and Practical Conference. Volume 1, 2009, pp. 24 -31 
[10] Būmane Sk., Poiša L., Čubars E., Platače R. The analysis of carbon content in different energy crops. In: Nordic view to sustainable rural development, 2015, pp. 156-160 [online][16.02.2019] Available at: http://llufb.llu.lv/conference/NJF/NJF_2015_Proceedings_Latvia-156-160.pdf (In Latvian)

[11] Lazdiņa D., Lazdiņš A., Bārdulis A. Daudzgadīgastiebrzāļuenergokultūra - miežabrālis. (Lazdiņa D., Lazdiņ̌̌ A., Bārdulis A. Perennial herbaceous energy crop - reed canary grass)Salaspils: Silava, 2008, 10 p. (In Latvian.)

[12] Bridgeman T.G., Jones J.M., Shield I., Williams P.T. Torrefaction of reed canary grass, wheat straw and willow to enhance solid fuel qualities and combustion properties. Fuel, No. 87, 2008, pp. 844-856. 